\title{
Yielding of Winter Triticale Varieties in Different Protection Levels in Two Sequence Systems
}

\author{
Ewa Adamiak, Dagmara Szałczyńska and Jan Adamiak \\ Department of Agroecosystems, Faculty of Environment and Agriculture, University of Warmia and Mazury in Olsztyn, Plac Łódzki \\ 3, 10-719 Olsztyn, Poland
}

\begin{abstract}
Five-year trials (2011-2015) were accomplished in a continuous field experiment conducted at the Production and Research Station in Bałcyny. The experiment was set up on a luvisol medium soil, derived from light loam with the objective of evaluating the response of two winter triticale varieties (Pigmej and Cyrkon) to cultivation without protection (O), chemical weed control $(\mathrm{H})$ and combined protection against weeds and fungi (HF). Comparisons were made in two crop sequence systems: cultivation of winter triticale varieties in a 6-field crop rotation and cultivation in a 19-23-year-long monoculture. The results showed that the plant sequence system significantly differentiated the response of winter triticale varieties to the applied levels of field protection. Significantly higher grain yield gains of the winter triticale varieties in response to the application of herbicides or herbicides with fungicides were obtained in the monoculture than in the crop rotation. In the crop rotation, a higher increase in yields induced by the applied plant protection treatments was achieved by the variety Cyrkon. In the monoculture, the response of both varieties to the herbicides applied was nearly identical, while the combined application of herbicides and fungicides raised the yields of var. Pigmej higher than those of var. Cyrkon. Overall for the plant protection levels, var. Cyrkon yielded higher than var. Pigmej by $18.1 \%$ more in the crop rotation and by $26.9 \%$ in the monoculture. At the same time, var. Cyrkon demonstrated a weaker response to being grown in the monoculture than var. Pigmej did. The average yield of the former was reduced by $21.1 \%$, whereas the latter yielded $26.6 \%$ less grain.
\end{abstract}

Key words: Winter triticale, varieties, crop rotation, monoculture, protection level.

\section{Introduction}

The high (over 70\%) share of cereals in the structure of agricultural crops sown in Poland makes it difficult to ensure that particular species will always have suitable preceding crops, typically, the field cropped with wheat. By necessity, other species, including triticale, are sown after wheat or after other cereals. The consequence of such rotations is the decrease in yields, but the largest loss when cereals are grown in cereal monocultures $[1,2]$. The principal causes are more severe weed infestation and higher incidence of stem-base diseases [3-5]. As rather sensitive to diseases, winter triticale belongs to cereals distinguished by a low level of competitiveness towards weeds. Chemical protection is required to

Corresponding author: Jan Adamiak, professor, research fields: crop sequence systems and plant protection. obtain high yields, especially when triticale is grown after cereals. The literature discussing the response of winter triticale to chemical weeding points that application of herbicides raises winter triticale yields by $0 \%-39 \%$. The yield increase depends on the crop sequence system, share of cereals in crop rotation, choice of the preceding crop and variety as well as the herbicide applied [1, 6-9]. The beneficial influence of fungicides is documented by a $2 \%-9 \%$ increase in winter triticale yields [1, 4, 5, 10-12].

In view of the above considerations, the research hypothesis assumed that continuous cultivation of winter triticale in different crop rotation system could differentiate its response to the level of chemical protection. The hypothesis was verified through studies conducted in a long-term field experiment to evaluate yields of two winter triticale varieties grown in two plant sequence systems: a 6-field crop rotation 
and a continuous monoculture, under the influence of different levels of chemical protection.

\section{Materials and Methods}

The study was conducted in a continuous field experiment, located at the Production and Research Station in Bałcyny near Ostróda, with 5-year-long trials between 2011 and 2015, and established on a luvisol medium soil, derived from light loam lying on loamy sand. With regard to agricultural suitability, the soil was classified as soil valuation classes IIIa and IIIb, a good wheat complex.

The design of the experiment included three factors arranged in a split-split-plot set-up:

(1) Two crop sequence system: (a) growing winter triticale in a 6-field crop rotation: potato-oat-fibre flax-winter rye-broad bean-winter triticale and (b) growing triticale in a 19-23-year-long monoculture.

(2) Three levels of chemical protection of fields: no chemical protection $(\mathrm{O})$, protection from weeds $(\mathrm{H})$ and protection from weeds and fungal diseases (HF).

(3) Two varieties of winter triticale: (a) Pigmej, a semi-dwarf variety with good yields $(99 \%$ of the reference), moderate frost resistance (5 on a 1-9 scale, where 1 was the worst value and 9 was the best), very good resistance to brown rust (8.6), good resistance to powdery mildew of cereals (7.6) and to Fusarium head blight (8.0), moderate resistance to septoria leaf (7.1) and glume blotch (7.2) and good resistance to stem-base diseases (8.1); (b) Cyrkon, normal type, with very high yields (108\% of the reference), low frost tolerance (3.5), good resistance to brown rust (8.1), very good to Fusarium head blight (8.5), moderate resistance to other leaf and ear (6.6-7.1), and good resistance to stem-base diseases (8.2).

The triticale varieties were sown in amounts of 400 germinating seeds $/ \mathrm{m}^{2}$, on dates considered the optimal for the species, between September 14 and 24 . Identical fertilization was applied in both crop sequence systems, consisting of $184 \mathrm{~kg} \mathrm{NPK} / \mathrm{ha}$ (N 70 $\mathrm{kg}, \mathrm{P} 31 \mathrm{~kg}$ and $\mathrm{K} 83 \mathrm{~kg}$ ). In addition, manure in a dose of 15 ton/ha was applied every three years in the winter triticale monoculture to balance the natural fertilization used under potato in the rotation system. Weeds were controlled with the herbicide Komplet $560 \mathrm{SC}$ (i.e., diflufenican + flufenacet) at $0.5 \mathrm{~L} / \mathrm{ha}$ in 2011 and 2012, and with the preparation Trinity 590 $\mathrm{SC}$ (i.e., diflufenican + chlorotoluron + pendimethalin) at $2.0 \mathrm{~L} / \mathrm{ha}$ in 2013-2015 applied in the autumn at the winter triticale developmental stage $\mathrm{BBCH}$ 13-17. Fungal diseases were controlled with sprays of the following fungicides in L/ha: $1.5 \mathrm{~L}$ Capalo $337,5 \mathrm{SE}$ (fenpropimorph + metrafenone + epoxiconazole), 0.6 L Amistar 250 SC (azoxystrobin), 0.4 L Artea 330 EC (propiconazole + cyproconazole), 1.0 L Fandango 200 $\mathrm{EC}$ (prothioconazole + fluoxastrobin) performed twice during the growth of winter triticale $(\mathrm{BBCH}$ 31-35 and BBCH 57-60).

Statistical analyses were performed using Statistical Software version No. 10. Means were compared at the $\alpha=0.05$ level by the Duncan's multiple range test.

\section{Results and Discussion}

\subsection{The Response of Winter Triticale Varieties to Herbicide Treatments}

The winter triticale varieties selected for the study were different in the yielding and the extent of their response to the protection levels in the two cropping systems. In both crop sequence systems and with all chemical protection variants, the variety Cyrkon produced statistically higher yields by $18.2 \%$ in a crop rotation, by $26.9 \%$ in a monoculture and by $21.9 \%$ on average (Fig. 1). This variety possesses a much greater genetic potential for yielding than var. Pigmej. In the variants without chemical protection, the yielding of var. Cyrkon was $15.2 \%$ more than var. Pigmej in the crop rotation and $32.7 \%$ in the monoculture (Table 1). The larger difference in the chemically unprotected monoculture than in the analogous crop rotation variant was correlated with the intensity of weed infestation of fields during the flowering stage. In the 


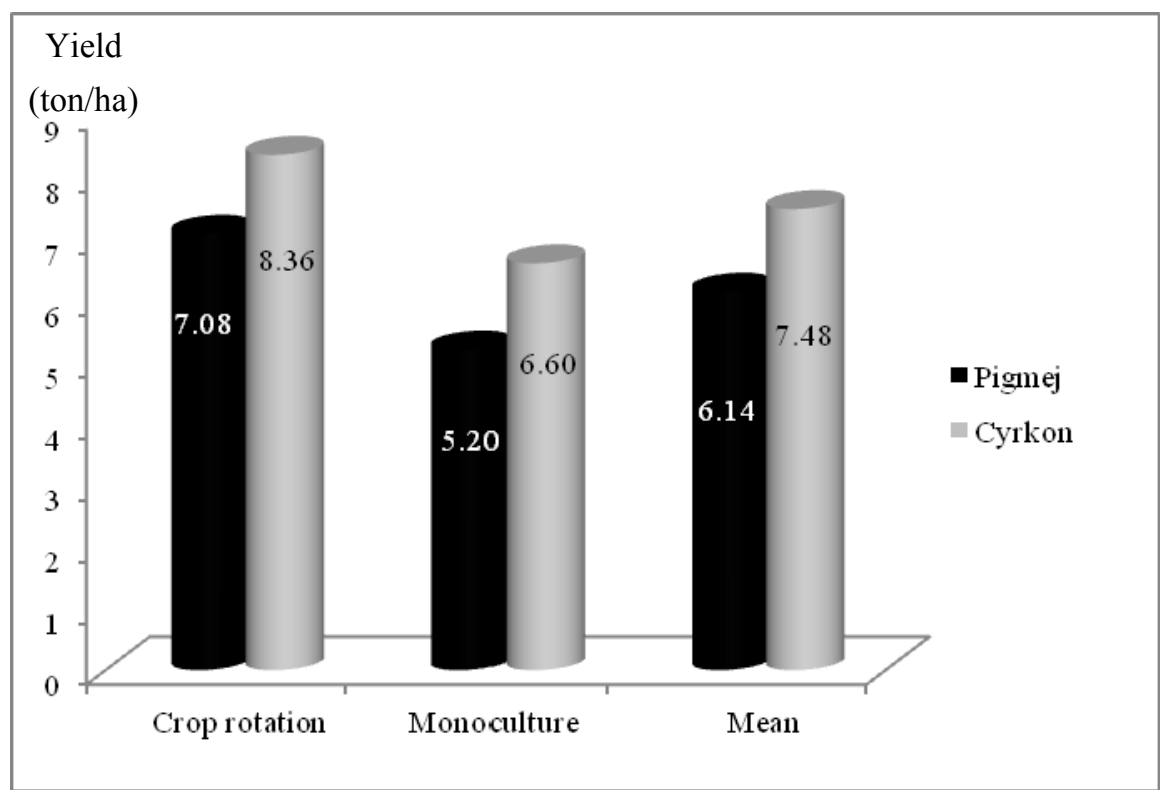

Fig. 1 Yield of winter triticale varieties in crop sequence systems.

$\mathrm{LSD}_{0.05}=0.37$ for varieties; interaction of sequence system and varieties was not significant.

Table 1 Mean yields of winter triticale grain in ton/ha for 2011-2015.

\begin{tabular}{|c|c|c|c|c|c|}
\hline \multirow[t]{2}{*}{ Protection levels } & \multirow[t]{2}{*}{ Varieties } & \multicolumn{2}{|c|}{$\begin{array}{l}\text { Mean yields of winter triticale grain } \\
\text { (ton/ha) }\end{array}$} & \multirow{2}{*}{$\begin{array}{l}\text { Mean for protection } \\
\text {-levels }\end{array}$} & \multirow[t]{2}{*}{$\mathrm{LSD}_{0.05}$} \\
\hline & & Crop rotation & Monoculture & & \\
\hline \multirow{3}{*}{ Without protection } & Pigmej & 6.76 & 3.91 & \multirow{3}{*}{5.92} & \multirow{9}{*}{0.44} \\
\hline & Cyrkon & 7.79 & 5.19 & & \\
\hline & Mean & 7.28 & 4.55 & & \\
\hline \multirow{3}{*}{ Protection from weeds } & Pigmej & 6.97 & 5.48 & & \\
\hline & Cyrkon & 8.38 & 7.28 & 7.03 & \\
\hline & Mean & 7.68 & 6.38 & & \\
\hline \multirow{3}{*}{ Protection from weeds and diseases } & Pigmej & 7.50 & 6.22 & \multirow{3}{*}{7.49} & \\
\hline & Cyrkon & 8.90 & 7.34 & & \\
\hline & Mean & 8.20 & 6.78 & & \\
\hline Mean for crop sequence system & & 7.72 & 5.90 & & \\
\hline $\mathrm{LSD}_{0.05}$ & & \multicolumn{2}{|c|}{0.60} & & \\
\hline $\begin{array}{l}\text { Interaction of sequence system and } \\
\text { protection levels }\end{array}$ & 0.40 & & & & \\
\hline $\begin{array}{l}\text { Interaction of sequence system and } \\
\text { varieties }\end{array}$ & NS & & & & \\
\hline $\begin{array}{l}\text { Interaction of protection levels and } \\
\text { varieties }\end{array}$ & 0.38 & & & & \\
\hline $\begin{array}{l}\text { Interaction of protection levels, } \\
\text { sequence system and varieties }\end{array}$ & NS & & & & \\
\hline
\end{tabular}

NS: not significant.

monoculture field cropped with var. Pigmej, the density of weeds (363 individuals $/ \mathrm{m}^{2}$ ) was $27 \%$ greater than in the field sown with var. Cyrkon. In the crop rotation, the number of weeds was higher in a field planted with var. Cyrkon (139 individuals $/ \mathrm{m}^{2}$ ). The application of chemical weed control preparations significantly increased the yielding of winter triticale, both in the crop rotation (by 5.5\%) and even more in the monoculture (by 40.2\%). The difference in the response was statistically proven, as supported by the interaction of plant sequence system $\times$ protection level. A more detailed analysis shows that when grown in the crop rotation, a higher and significant increase in grain yield $(+7.6 \%)$ was achieved by var. Cyrkon. The 
variety Pigmej grown in the same system only showed an increasing tendency $(+3.1 \%)$ regarding grain yield. In the monoculture, this variant of plant protection raised the productivity of both varieties significantly and practically to the same extent (Pigmej by $40.2 \%$ and Cyrkon by $40.3 \%$ ). In the consequence of such an impact of the herbicides, the difference in yields to the advantage of var. Cyrkon grown in the crop rotation increased to $20.2 \%$, while remaining on the same level $(32.8 \%)$ in the monoculture. The positive influence of herbicides on yields of winter triticale grown in a monoculture has been reported by many authors. Kraska and Pałys [7], who completed studies on a 5-year monoculture, achieved yields higher by $28.1 \%$ to $37.6 \%$, depending on doses of herbicides, from three winter triticale varieties (Janko, Krakowiak, Woltario). No significant differences were determined in the response of these three varieties to herbicide applications, and var. Woltario proved to be a significantly better yielding variety. A similar increase (32.4\%-39.1\%) in yields of winter triticale was reported by Kwiecińka-Popoe et al. [8] from a 3-year monoculture of the variety Todan. Studies involving the same long-term experiment [1], as reported in this paper, demonstrated that during the first six years (1993-1998) of a monoculture, herbicides increased the yields of winter triticale varieties Malno and Tewo to the same degree, by $11.9 \%$ on average. Both varieties grown after broad bean in a 6-field crop rotation system responded to the application of herbicides by decreasing yields, although the yielding of var. Malno suffered more (less by $5.4 \%$, significantly) than that of var. Tewo (less by $3.0 \%$ ). Similarly, in the research by Stankiewicz [13], the spring triticale variety Wanad did not respond to different doses of the herbicides Arelon 75 WP and Puma Super 069 EW by increasing its yield. In contrast, Piech and Maciorowski [6] obtained positive results. Winter triticale sown in a field severely infested with weeds after winter oilseed rape produced grain yields higher by $0.8 \%$ to $9.0 \%$, depending on the applied herbicide.

\subsection{The Response of Winter Triticale Varieties to Fungicide Treatments}

Application of both herbicides and fungicides, compared to the unprotected field, significantly raised the grain yields of winter triticale in both crop sequence system by $12.6 \%$ in the crop rotation and by $49.0 \%$ in the monoculture (Table 1). In the crop rotation, a higher yield increase was achieved by var. Cyrkon $(+14.2 \%)$ than by var. Pigmej $(+7.6 \%)$, but the situation was reverse in the monoculture, namely, var. Pigmej gained a higher yield increase $(+59.1 \%)$ than var. Cyrkon $(+41.4 \%)$. With respect to this combined yield-protecting effect of herbicides and fungicides, it seems necessary to explore the role of fungicides in shaping the yields of the two varieties. In both plant sequence systems, var. Pigmej responded with a relatively higher yield increase to the application of fungicides. While the increase in yields of both varieties in the crop rotation was similar, and equalled $7.6 \%$ for var. Pigmej and $6.2 \%$ for var. Cyrkon, the yielding of var. Pigmej improved significantly in the monoculture (by 13.5\%), but var. Cyrkon produced yields higher by $0.8 \%$. The application of fungicides in the reported experiment increased yields of winter triticale on average for both varieties by $6.8 \%$ in the crop rotation and by $6.3 \%$ in the monoculture. Meanwhile, the combined application of herbicides and fungicides practically balanced the disproportions in yields of the varieties in both crop sequence systems. The difference to the advantage of var. Cyrkon in the crop rotation decreased by $18.6 \%$ and in the monoculture by $18 \%$. In a previous study, conducted on the same field experiment in 1993-1998 by Adamiak et al. [1], the positive role of fungicides in forming yields of winter triticale was not significant. It improved the productivity of winter triticale by $2.6 \%$ in a crop rotation and by $2.2 \%$ in a monoculture. Of the two varieties tested Malno and Tewo, var. Tewo proved to 
respond better to the application of fungicides. A study conducted by Adamiak et al. [4] showed that fungicides raised winter triticale yields higher in a crop rotation (by 10.7\%) than in a monoculture (by 2.3\%), and when Marko and Tewo were compared, they responded similarly to the application of these chemicals. Similarly, Adamiak et al. [10] obtained an increase in winter triticale yields of $15.6 \%$ in a crop rotation and $10.5 \%$ in a monoculture following fungicidal treatments, and in both plant sequence systems, the variety Woltario responded more positively to fungicidal protection. It improved its productivity by $19.4 \%$ and $14 \%$, respectively, while var. Witon produced yields higher by $11.2 \%$ and $6.1 \%$. This was attributed to effective protecting of fungicides against a more severe infection of winter triticale with leaf and ear diseases in rotation system. The positive influence of fungicides on yields of winter triticale grown after a mixture of cereals and leguminous plants has also been reported by Wróbel and Jabłoński [11], who demonstrated that depending on the applied protection measures, the grain yield increased from $3.8 \%$ to $18.0 \%$, with the smallest gain achieved when only stem-base diseases were controlled. According to Gutteridge et al. [5], the plant protective efficiency of fungicides depends on the severity of diseases.

The results presented above also demonstrate the significant role of chemical plant protection in inhibiting the reduction of winter triticale yields in a continuous monoculture. The principal role in this process is ascribed to herbicides. Their application reduced a decline in winter triticale grain yield, on average, from $37.5 \%$ in the unprotected field to $17.1 \%$ in the herbicide-treated variant (Table 1). This is unsurprising, as the major factor limiting yields of cereals in monocultures is excessive weed infestation $[3,7,8]$. In the current study, the inhibition of yield losses was similar for both varieties: $21.4 \%$ for var. Pigmej and $20.3 \%$ for var. Cyrkon. Fungicides as an anti-tiredness factor were effective only in the cultivation of var. Pigmej, where they reduced a decrease in its grain yields in the monoculture by a further $4.3 \%$ up to $17.1 \%$. Regarding var. Cyrkon, relative to the field treated with herbicides alone, fungicides increased the yield from $4.4 \%$ to $17.5 \%$. Considering the average for the varieties, an application of fungicides relative to the field treated with herbicides alone minimally enlarged the decline in winter triticale grain yield in the monoculture. The fact that fungicides do not play any anti-tiredness role in a monoculture of winter triticale has been reported by Adamiak et al. [1, 4, 10]. The reason is that the applied fungicides are very good at reducing the incidence of leaf and ear diseases, which are the ones that infect fields in a crop rotation more severely than in monocultures.

On average for the protection levels, both varieties responded to the continuous monoculture by a significant decrease in yields, and the variety Pigmej had lower yields (by 26.4\%) than var. Cyrkon (by $21.1 \%$ ). These results suggest that, to some extent, the negative effects of a monoculture can be compensated for by an adequate selection of varieties.

\section{Conclusions}

It has been demonstrated that the crop sequence systems significantly differentiated the response of the winter triticale varieties to the applied plant protection chemicals. In the treatment with herbicides or with herbicides and fungicides, higher gains in grain yields were obtained in the monoculture than in the rotation. It was only the variety Cyrkon that responded to the chemical weed control in crop rotation by a significantly higher yield. In the monoculture, both varieties improved their yielding significantly and to a comparable degree. The application of fungicides in the crop rotation improved the yields of var. Cyrkon only minimally better than those of var. Pigmej. Conversely, fungicidal treatments in the long-term monoculture contributed to higher yields of var. Pigmej. Chemical plant protection proved to be a 
significant factor reducing the decrease in grain yields harvested from winter triticale grown in the monoculture. Its anti-tiredness effect was manifested much more distinctly in respect of var. Pigmej than var. Cyrkon. Irrespective of the crop sequence system or the plant protection variant, the variety Cyrkon demonstrated higher productivity. Also, this variety responded to the 19-23-year-long continuous monoculture with a smaller decrease in grain yields.

\section{References}

[1] Adamiak, E., Adamiak, J., and Zawiślak, K. 2000. "Response of Winter Triticale to Six-Year Monoculture." Folia Univ. Agric. Stetin. 206-Agricultura (82): 9-14. (in Polish)

[2] Smagacz, J., and Kuś, J. 2010. "Influence of Cereal Crop Rotation on Yielding of Cereals and Selected Chemical Soil Properties." Fragm. Agron. 27 (4): 119-34. (in Polish)

[3] Adamiak, E., and Adamiak, J. 1998. "Effect of Crop Sequence and Herbicides on Weed Infestation of Winter Triticale." Rocz. Nauk Rol. Seria A T. 113 Z. 3-4: 63-71. (in Polish)

[4] Adamiak, E., Kurowski, T. P., and Adamiak, J. 2003. "Disease Infestation of Winter Triticale Varieties in Long Term Monocultures." Mitt. Ges. Pflanzenbauwiss. 15: 296-7. (in Germany)

[5] Gutteridge, R. J., Bateman, G. L., and Todd, A. D. 2003. "Variation in the Effects of Take-All Disease on Grain Field and Quality of Winter Cereals in Field Experiments." Pest Management Sci. 59 (2): 215-24.

[6] Piech, M., and Maciorowski, R. 1998. "The Reaction of
Winter Triticale Varieties to Herbicides Evaluated in Field Trials." Biul. IHAR 205/206: 279-87. (in Polish)

[7] Kraska, P., and Pałys, E. 2008. "Grain Yielding and Chemical Composition of Winter Triticale Cultivated in Monoculture in Conditions of Different Doses Herbicides." Annales UMCS Section E 63 (2): 1-7. (in Polish)

[8] Kwiecińska-Popp, E., Kraska, P., Andruszczak, S., and Pałys, E. 2010. "Yield and Grain Quality Characteristics of Winter Triticosecale Cultivated in Monoculture in Conditions of Application of Different Herbicide Doses and Foliar Fertilization." Prog. Plant Prot. 50 (2): 999-1003. (in Polish)

[9] Wielogórska, G., Turska, E., and Starczewski, J. 2010. "Cultivation Technology and Winter Triticale Yields in Central-Eastern Poland." Folia Pomer. Univ. Technol. Stetin-Agric. Aliment. Pis. Zootech. 276 (13): 61-6. (in Polish)

[10] Adamiak, J., Adamiak, E., and Bruderek, A. 2008. “The Effect of Unix 75 WG Fungicide on Grain Yield of Winter Triticale Cultivated in Crop Rotation and Long Term Monoculture.” Prog. Plant Prot. 48 (1): 255-8. (in Polish)

[11] Wróbel, E., and Jabłoński, H. 2004. "Effect of Fungal Diseases Control Methods on Winter Triticale Field." Acta Sci. Pol. Agri. 3 (1): 55-61. (in Polish)

[12] Pecio, A., and Bichoński, A. 2008. "Effect of Plant Protection against Diseases and Nitrogen Fertilization on Winter Triticale Grain Field and Quality." Fragm. Agron. 4: 79-88.

[13] Stankiewicz, C. 2004. "Effect of Sowing Density, Herbicides and Harrowing Application on Field and Content of Total Protein and Starch in 'Wanad' Spring Triticale Kernels.” Acta Sci. Pol. Agri. 3 (1): 77-88. (in Polish) 